\title{
Correction to: Creative, embodied practices, and the potentialities for sustainability transformations
}

\author{
Julia Bentz ${ }^{1,2}(1) \cdot$ Letícia do Carmo $^{3} \cdot$ Nicole Schafenacker $^{4} \cdot J_{o ̈ r n}$ Schirok $^{5} \cdot$ Sara Dal Corso $^{6}$
}

Published online: 5 August 2021

(c) The Author(s) 2021

\section{Correction to: Sustainability Science https://doi.org/10.1007/s11625-021-01000-2}

In the original publication of the article, the affiliation details for author "Sara Dal Corso" were incorrectly tagged with five institutions. The author "Sara Dal Corso" is an independent artist and the affiliation should have been "Lisbon, Portugal".

The original article was updated.

Open Access This article is licensed under a Creative Commons Attribution 4.0 International License, which permits use, sharing, adaptation, distribution and reproduction in any medium or format, as long as you give appropriate credit to the original author(s) and the source, provide a link to the Creative Commons licence, and indicate if changes were made. The images or other third party material in this article are included in the article's Creative Commons licence, unless indicated

The original articles can be found online at https://doi.org/10. 1007/s11625-021-01000-2.

Julia Bentz

juliabentz@gmail.com

1 CICS.NOVA Interdisciplinary Centre of Social Sciences, University Nova Lisboa, Colégio Almada Negreiros, Campus de Campolide, 1070-312 Lisbon, Portugal

2 Centre for Ecology, Evolution and Environmental Changes (ce3c), Faculty of Sciences, University of Lisbon, Campo Grande, Building C1, 4th floor, room 38, 1749-016 Lisbon, Portugal

3 Centro de Comunicação e Representação Espacial (CCRE) of Centro de Estudos de Arquitectura e Urbanismo (CEAU), Faculdade de Arquitectura da Universidade do Porto (FAUP), Via Panorâmica, S/N, 4150-564 Porto, Portugal

4 Health Arts Research Centre, University of Northern British Columbia, Room 9-380 Dr. Donald R. Rix Northern Health Sciences Centre, University of Northern British Columbia, 3333 University Way, Prince George, BC V2N 4Z9, Canada

5 Institute of Geography, Osnabrück University, 49069 Osnabrück, Germany

6 Lisbon, Portugal otherwise in a credit line to the material. If material is not included in the article's Creative Commons licence and your intended use is not permitted by statutory regulation or exceeds the permitted use, you will need to obtain permission directly from the copyright holder. To view a copy of this licence, visit http://creativecommons.org/licenses/by/4.0/.

Publisher's Note Springer Nature remains neutral with regard to jurisdictional claims in published maps and institutional affiliations. 